\title{
MULHER, QUEBRADEIRA DE COCO, MILITANTE NA AMAZÔNIA: \\ CONSTITUIÇÃO SUBJETIVA E AUTORIA EM SOU FILHA DE \\ QUEBRADEIRA DE COCO BABAÇU
}

\author{
WOMAN, BABASSU COCONUT BREAKER, MILITANT IN \\ AMAZONIA: SUBJECTIVE CONSTITUTION AND AUTHORSHIP IN \\ SOU FILHA DE QUEBRADEIRA DE COCO BABAÇU
}

Nilsa Brito Ribeiro ${ }^{1}$, Solange Mittmann ${ }^{2}$

\begin{abstract}
RESUMO: Neste artigo, tomamos como objeto de estudo recortes da narrativa de vida de Cledeneuza Maria Bizerra Oliveira, liderança do Movimento Interestadual das Quebradeiras de Coco Babaçu (MIQCB), publicada no livro Sou filha de quebradeira de coco babaçu. A fim de discutir a constituição subjetiva de uma mulher amazônida em sua vida de militância, abordamos o próprio da língua em sua equivocidade e realizamos gestos de análise de formulações indicativas de lugares ocupados, posições assumidas e designação de si - como professora, quebradeira de coco babaçu, filha de quebradeira de coco, esposa, líder sindical. Deparamo-nos com um sujeito que transita entre tempos, espaços e territorialidades que caracterizam campos simbólicos onde se produzem os sentidos. E pela autoria observamos a disputa por sentidos na luta política diária, onde não há fronteiras evidentes entre a constituição individual e a construção coletiva.
\end{abstract}

PALAVRAS-CHAVE: quebradeira de coco babaçu; resistência feminina; autoria; relato de vida

\begin{abstract}
In this article, we take as an object of study the life story clippings of Cledeneuza Maria Bizerra Oliveira, leader of the Interstate Movement of the Babassu Coconut Breakers (MIQCB), published in the book I am a daughter of the babassu coconut breaker. In order to discuss the subjective constitution of an Amazonian woman in her life of militancy, we approach the language itself in its equivocity and we perform analyze gestures of indicative formulations of occupied places, assumed positions and self-designation - as a teacher, babassu coconut breaker, daughter of coconut breaker, wife, union leader. We have faced with a subject who transits between times, spaces and territorialities that characterize symbolic fields where the senses are produced. And by the authorship we observe the dispute for meanings in the daily political struggle, where there are not evident borders between the individual constitution and the collective construction.
\end{abstract}

\footnotetext{
${ }^{1}$ Doutora em Linguística pela UNICAMP. Professora da UNIFESSPA e docente do PPG Dinâmicas Territoriais e Sociedade na Amazônia e do PPG Linguagem e Sociedade. Projeto com apoio CAPES; PROCADAMAZÔNIA.

${ }^{2}$ Doutora em Letras pela UFRGS. Professora da UFRGS e docente do PPG-Letras da UFRGS.
} 
KEYWORDS: Babassu coconut breaker woman; female resistance; authorship; life story.

A propósito de uma problematização a respeito das disciplinas de interpretação em cujo domínio se situa a Análise de Discurso, Pêcheux (2008 [1983]) produz uma reflexão importante sobre o gesto inaugural de novas práticas de leitura operado com a revolução cultural estruturalista desenvolvida na França na década de 1960, através do encontro promovido entre as bases teóricas de Marx, Freud e Saussure. A convergência entre essas bases epistemológicas coloca em causa as evidências da relação dual entre o biológico e o social, fazendo intervir o simbólico e o significantes nesta relação, ou seja, concebendo um tipo de real que se estrutura no entrecruzamento da língua e da história (PÊCHEUX, 2008 [1983]).

Mas é Pêcheux mesmo quem vai formular uma crítica contundente a esse movimento antipositivista que se constituiu na recusa às "certezas científicas" sobretudo porque tal movimento entra em um desvio teórico cedendo aos encantos da lógica conceitual e universalizante. Em outras palavras, o abandono de interpretação lastreada na descrição textual é substituído por uma "sobre-interpretação" estruturalista que funciona como um "dispositivo de tradução", nos termos de Pêcheux (2008 [1983], p.146).

É no bojo dessa crítica que Pêcheux se aproxima das análises que, paralelamente ao desenvolvimento do estruturalismo político francês, surgem com os estudos de Lacan, Barthes, Derrida e Foucault, destacando a necessidade de um olhar teórico que se volte também para o que ocorre nas emergências do cotidiano e não somente para a estrutura dominante. Os estudos desenvolvidos pela Nova História são apontados por Pêcheux como exemplo de preocupações teóricas com os discursos que ocorrem no cotidiano como formas de resistência. No entanto, a adesão do autor à proposta de se colocar na posição de entender os discursos por vezes silenciosos vem acompanhada da advertência em relação aos riscos de uma abordagem como esta, sob pena de vir a repetir o que fazem certas vertentes ideológicas que lidam com os sentidos do cotidiano como "um fato de natureza psico-biológica, inscrito em uma discursividade logicamente estabilizada. Logo, o risco de um retorno fantástico para os positivismos e filosofias da consciência” (PÊCHEUX, 2008 [1983], p.49). Nesse sentido, a superação de tal risco (teórico e metodológico) é enfrentada por Pêcheux através da articulação entre a análise do discurso do cotidiano e a leitura dos arranjos textuais-discursivos, ou seja, trabalha os arranjos discursivos textuais inscritos na história.

$\mathrm{Na}$ esteira do interesse de aproximação desses dois domínios propostos por Pêcheux, descartando qualquer perspectiva de análise que privilegie uma abordagem fenomenológica ou 
hermenêutica, mas, ao contrário, reconhecendo o equívoco como o próprio da língua e a heterogeneidade como constitutiva, é que temos como objetivo central deste trabalho desenvolver gestos de análise sobre uma narrativa pessoal, abordando o próprio da língua em sua equivocidade, em sua heterogeneidade constitutiva, ou seja, colocando em suspensão as evidências do que se diz sobre o vivido, articulando, inscrevendo nas contradições movidas pelo equívoco e pela historicidade. Assim, situamos a narrativa de uma história de vida no domínio do que Pêcheux considera discursos da urgência às voltas com mecanismos de sobrevivência. Trata-se de apreender como se cruzam mecanismos políticos e efeitos de discursos.

Em "A vida dos homens infames", Foucault (2006[1977]) nos fala do seu encontro com alguns textos produzidos nas esferas administrativas e políticas, nos séculos XVII e XVIII, cujas narrativas se ocupavam da vida cotidiana de sujeitos que sempre estiveram à margem das esferas do poder, aliás sequer eram falados na sociedade como sujeito de uma vida. Segundo Foucault, é esta presença-ausência que aguça seu interesse por estes tipos de vida: existências sem nomes, marcadas de aventuras e desventuras, encontradas por acaso, registradas em relatos condensados e rápidos. Mas, nem por isso ou, talvez, por isso mesmo, essas vidas anônimas deixam de operar um rasgão no tecido social, expondo a debilidade ética da sociedade da exclusão.

[...] nesses textos, a condensação das coisas ditas, que não se sabe se a intensidade que os atravessa deve-se mais ao clamor das palavras ou à violência dos fatos que neles se encontram. Vidas singulares, tornadas, não sei quais acasos, estranhos poemas, eis o que eu quis juntar em uma espécie de herbário. (FOUCAULT, 2006[1977], p. 205).

Lembra Foucault que o seu interesse pelo registro dessas vidas ínfimas, em alguns documentos das esferas administrativas e políticas, é pelo sonho de restituir sua potência, sua intensidade, em uma análise que procura conhecer o que leva as instituições ou práticas políticas a preferirem tais discursos ${ }^{3}$. O interesse de Foucault estaria, portanto, em apreender os efeitos da vida social sobre esses sujeitos e, ao mesmo tempo, em entender o quanto a sociedade foi atravessada por eles, afetada pela sua miserável existência: "armadilhas, armas, gritos, gestos, atitudes, astúcias, intrigas cujas palavras foram o instrumento" (FOUCAULT, 2006[1977], p. 207). Assim, poder e resistência constituem a relação inextrincável que move o interesse de

\footnotetext{
${ }^{3}$ A seguir, um registro de internamento encontrado por Foucault, na Biblioteca Nacional, como exemplo de discursos de vidas ínfimas: Mathurin Milan, posto no hospital de Charenton no dia 31 de agosto 1707: 'Sua loucura sempre foi a de se esconder de sua família, de levar uma vida obscura no campo, de ter processos, de emprestar com usura a fundo perdido, de vaguear seu pobre espírito por estradas desconhecidas, e de se acreditar capaz das maiores ocupações" (FOUCAULT, 2006[1977], p. 204). 
Foucault em captar a luta insidiosa de um jogo de forças em que se cruzam "mecanismos políticos e efeitos de discurso".

O ponto mais intenso das vidas, aquele em que se concentra sua energia, é bem ali onde elas se chocam com o poder, se debatem com ele, tentam utilizar suas forças ou escapar de suas armadilhas. As falas breves e estridentes que vão e vêm entre o poder e as existências as mais essenciais, sem dúvida, são para estas o único monumento que jamais lhe foi concedido; é o que lhes dá para atravessar o tempo, o pouco de ruído, o breve clarão que as traz até nós. (FOUCAULT, 2006[1977], p. 208).

É sob a visada de Pêcheux, em identificar a necessidade histórica de a Análise de Discurso se voltar para "as múltiplas urgências do cotidiano" e o interesse de Foucault em se colocar à escuta de existências infames, que procuramos apreender na narrativa de vida de uma mulher integrante do Movimento Interestadual das Quebradeiras de Coco Babaçu (daqui em diante MIQCB) como, nos discursos do cotidiano, se mostram as relações com o poder e, ao mesmo tempo, como este incita as resistências. Descartando qualquer evidência da linguagem e do sujeito com pleno domínio do que narra sobre sua própria existência, nossas análises focalizam a materialidade discursivo-textual inscrita na história, de modo a reconhecer a contingência e a historicidade em que se inscreve o modo como o sujeito se reconhece enquanto experiência de si implicada em posições ideológicas que guardam relações com o poder e com as resistências.

Em História da sexualidade 2: o uso dos prazeres, Foucault (1984[1966]) se dedica, também, ao sujeito das práticas cotidianas, evidenciando que, se por um lado, as contingências históricas atuam na determinação das práticas dos sujeitos que atuam nas esferas cotidianas, por outro lado, esses sujeitos agem, de alguma forma, no interior mesmo das determinações do poder, na construção de práticas de liberdade, resistências, éticas de si, justamente porque não há poder sem resistências, o que não descarta o exercício da dominação.

O poder que produz em suas estratégias de dominação a perseguição dessas sujeitos ordinários (DE CERTEAU, 1994[1980]), paradoxalmente, é o mesmo poder que suscita a sua existência através de pequenas revoltas na relação com o poder, de modo que, para Foucault, as resistências não surgem externamente ao poder, já que dele elas são constitutivas.

\section{A narradora como sujeito e como autora de uma trajetória pessoal e política}

Apresentar como objeto de estudo uma narrativa de vida traz o risco de uma leitura calcada na ilusão de um ente individual, origem e mestre de seu dizer. Por isso, faz-se necessário discutir teoricamente a questão da subjetividade desde uma perspectiva discursiva. 
"Seria absurdo negar, é claro, a existência do indivíduo que escreve e inventa", reconhecemos com Foucault (1996 [1970], p.28). Como seria absurdo desconsiderar, na análise de sequências discursivas do livro Sou filha de quebradeira de coco babaçu, a existência dos indivíduos autores Cledeneuza Maria Bizerra Oliveira, que narra sua história e cuja foto consta na capa, e Alfredo Wagner de Almeida, que edita a narração em livro. E nomes de indivíduos sustentam nomes de autor:

[...] pede-se que o autor preste contas da unidade de texto posta sob seu nome; pedese-lhe que revele, ou ao menos sustente, o sentido oculto que o atravessa; pede-se-lhe que o articule com sua vida pessoal e suas experiências vividas, com a história real que o viu nascer. $\mathrm{O}$ autor é aquele que dá à inquietante linguagem da ficção suas unidades, seus nós de coerência, sua inserção no real. (FOUCAULT, 1996[1970], p. 28)

Mas não é o indivíduo o foco dos estudos discursivos, e sim o sujeito (como lugar ou posição), e essa determinação de foco sustenta a concepção de autor; também não é o indivíduo autor que importa em uma análise discursiva, e sim o fato de a assinatura de um nome como nome de autor sinalizar a existência de uma função autor, um princípio de funcionamento que conduz a dispersão (característica do discurso e do sujeito) ao efeito de unidade (que faz com que uma materialidade seja reconhecida como um texto).

Na Arqueologia do saber, Foucault (2014[1969]) aborda a relação entre sujeito e discurso rejeitando a imagem de uma subjetividade psicológica, de um sujeito transcendente, causa, origem ou ponto de partida da articulação de uma frase, intenção significativa que ordenaria as palavras, ou ainda núcleo constante, imóvel de operações manifestas num discurso.

Foucault interroga sobre as determinações e consequências do status de quem fala, dos lugares institucionais de onde vêm os discursos, e das posições do sujeito definidas pelas situações que pode ocupar. E afirma que o discurso é "um conjunto em que podem ser determinadas a dispersão do sujeito e sua descontinuidade em relação a si mesmo", apresentando, então, a posição de sujeito como "um lugar determinado e vazio que pode ser ocupado por indivíduos diferentes", um lugar que "varia" no decorrer do texto, da mesma forma que "um único e mesmo indivíduo pode ocupar alternadamente diferentes posições" (FOUCAULT, 2014[1969], p.66, 109 e 107). Por isso, a análise de um discurso não busca identificar ou atribuir a ele um sujeito, e sim levantar um conjunto de posições subjetivas possíveis.

E considerando que o discurso "não é simplesmente aquilo que manifesta (ou oculta) o desejo; é também aquilo que é objeto do desejo" (FOUCAULT, 1996[1970], p. 8), cabe destacar que a relação entre tais lugares ocupados e a produção de discursos se dá de forma controlada: 
em toda sociedade a produção do discurso é ao mesmo tempo controlada, selecionada, organizada e redistribuída por certo número de procedimentos que têm por função conjurar seus poderes e perigos, dominar seu acontecimento aleatório, esquivar sua pesada e temível materialidade (FOUCAULT, 1996[1970], p. 8-9).

É levando em conta esses aspectos que Foucault situa a autoria como uma das formas de controle do discurso: "O autor, não entendido, é claro, como o indivíduo falante que pronunciou ou escreveu um texto, mas o autor como princípio de agrupamento do discurso, como unidade e origem de suas significações, como foco de sua coerência." (FOUCAULT, 1996 [1970], p.26) Portanto, podemos dizer que a função autor entra em cena a fim de evitar a dispersão e a aleatoriedade, organizando a polifonia e a polissemia, levando ao efeito de um: uma voz, um limite entre o dentro e o fora, um sentido. Ilusões necessárias à produção e à leitura.

Nesta abordagem discursiva sobre o sujeito, recorremos, outrossim, a Pêcheux (1993 [1969], p.82), quem também marca a diferença entre indivíduo e sujeito, abordando algo "diferente da figura física de organismos humanos individuais", optando pelo termo lugar, ao falar em "lugares determinados na estrutura de uma formação social" representados (isto é, presentes, mas transformados) nos processos discursivos. Desses lugares, configuram-se as formações imaginárias presentes na interlocução: a imagem que cada interlocutor faz do seu lugar e do lugar do outro, bem como a imagem que cada interlocutor faz da imagem que o outro faz do lugar dele mesmo e do seu lugar. Trabalham nessa interlocução e no processo discursivo, as relações de forças e as relações de sentidos; a aliança, mas também o conflito, o litígio, a disputa pela significação.

Posteriormente, e com base na descrição de Althusser do funcionamento da ideologia, Pêcheux (1995 [1975], p.214), afirma que "a interpelação do indivíduo em sujeito de seu discurso se realiza pela identificação (do sujeito) com a formação discursiva que o domina". Essa interpelação é respondida pelo sujeito através de uma tomada de posição, cujas modalidades citadas pelo autor são a identificação, a contra-identificação e a desidentificação. Portanto, é sob a determinação da formação discursiva que o domina que o sujeito "é interpelado em 'sujeito-responsável”, ou seja, “é colocado como autor de e responsável por seus atos (por suas 'condutas' e por suas 'palavras') em cada prática em que se inscreve”, tomando posição ante os saberes e as formas de determinação da formação discursiva em que se inscreve a cada vez.

Trabalham no processo discursivo dois esquecimentos (descritos por Pêcheux [1995 [1975]): o esquecimento da interpelação, com a ilusão da plena liberdade, e o esquecimento que 
é da ordem da enunciação, com a ilusão de controle sobre o próprio dizer, sobre os sentidos, sobre a interpretação do outro. Podemos arriscar dizer que a constituição da autoria, nesta perspectiva, se dá a partir do primeiro esquecimento, mas desemboca e se concretiza no segundo. Ou seja, para ser sujeito, o indivíduo precisa estar submetido à ideologia (e ele está desde sempre, como nos ensinam Althusser e Pêcheux); para significar, precisa estar inscrito numa rede de sentidos já-lá de uma formação discursiva (que é onde se discursivizam os saberes de uma formação ideológica). Ao mesmo tempo, precisa acreditar no pensamento livre e autônomo, crer-se origem de suas ideias e dono de seu dizer - ilusões necessárias.

Podemos afirmar, a partir das considerações sobre sujeito e autor apresentadas até aqui, que os lugares ocupados por Cledeneuza (quebradeira de coco e liderança sindical) lhe conferem o status de narradora de sua história (tomada como verdadeira e relevante a um público leitor) em livro publicado por uma instituição. Assim, apresenta, pelo discurso, suas posições - na trajetória pessoal e na atuação política - e assume a autoria, cuja função é articular em unidade a dispersão desses lugares e posições. Sua assinatura como autora de uma obra constituída por treze capítulos, em que apresenta narrativa(s) de sua própria trajetória é afiançada institucionalmente pela participação de sujeitos pesquisadores ${ }^{4}$, que a situam no universo autobiográfico dos estudos etnográficos.

Inquirida pela instituição acadêmica, interpelada pela ideologia, ocupando lugares sociais, inscrita em formações discursivas, assumindo posições, sob os efeitos dos dois esquecimentos necessários, é que encontramos uma imagem de Cledeneuza, mulher, quebradeira de coco, militante, com uma trajetória de vida a narrar.

\section{"Sou filha de quebradeira de coco": designação e constituição de si}

Como já referimos acima, as formulações analisadas neste trabalho são extraídas de relatos da trajetória de vida de Cledeneuza Maria Bizerra Oliveira, representante do MIQCB, publicados no livro Sou filha de quebradeira de coco babaçu, de autoria da própria narradora, sob a edição do antropólogo Alfredo Wagner de Almeida. A publicação compõe a coleção Narrativas de Quebradeiras de Coco Babaçu, organizada por pesquisadores do Projeto Nova Cartografia Social da Amazônia (PNCSA), em que "membros de diferentes unidades sociais,

\footnotetext{
${ }^{4}$ Alfredo Wagner Berno de Almeida (doutor em Antropologia, docente na Universidade do Estado do Amazonas e coordenador do Projeto Nova Cartografia Social da Amazônia) assina como editor da obra e escreve o texto de apresentação, situando o livro na Coleção Narrativas das Quebradeiras de Coco Babaçu, e Rita de Cássia Pereira da Costa (mestre em Antropologia, docente na Universidade Federal do Sul e Sudeste do Pará e pesquisadora do mesmo projeto) escreve o prefácio, onde descreve a participação de Cledeneuza no projeto e cita outros pesquisadores, além do apoio de instituições, como o IPHAN.
} 
designadas como povos e comunidades tradicionais, descrevem eles mesmos suas experiências de luta, em situações de conflito social, nas quais reivindicam seus direitos territoriais e suas expressões identitárias”. (ALMEIDA, 2017, p. 9) . $^{5}$

O MIQCB é um movimento formado de mulheres - com representações nos estados do Pará, Maranhão, Piauí e Tocantins - que há vários anos integram a atividade de quebrar o coco babaçu como a principal fonte de renda familiar. Além de uma atividade econômica, cultural e social, tem se constituído também "como um movimento de resistência e luta pelo direito de acesso aos recursos naturais e ao território, do qual muitas quebradeiras foram expulsas no histórico processo agrário do país" (SILVA, NAPOLITANO e BASTOS, 2016, p. 2). A narradora expõe esse trajeto bifurcado e entrecruzado de suas experiências a partir da ocupação dos lugares de mulher, mãe, esposa, professora, militante, quebradeira de coco etc.

Uma das possibilidades de entrada e apreensão da movência de sentidos produzida na narrativa de Cledeneuza é por meio do processo de nomeação de si, cujo efeito é o de uma tensão instaurada entre o trabalho autoral de produção e acomodação de sentidos sobre si, no que concerne à sua trajetória de lutas, e a denúncia de sentidos outros marcados pela opressão e exclusão de alteridades. Essa tensão entre captação e rejeição de sentidos materializados em processos de designação do sujeito se inscreve em diferentes formações discursivas que revelam a constituição heterogênea de um sujeito que ocupa diferentes lugares sociais e posições ideológicas, a partir de diferentes dispositivos.

Como discute Larrosa, "toda cultura inclui os dispositivos para a formação de seus membros como sujeitos ou, no sentido que vimos dando aqui à palavra 'sujeito', como seres dotados de certas modalidades de experiências de si” (LARROSA, 1994, p. 73). Trata-se, portanto, de diferentes experiências sócio-históricas e diferentes práticas discursivas. É dessa perspectiva anunciada por Larrosa que mobilizaremos na materialidade discursiva sentidos que remetem à experiência da narradora ocupando diferentes posições enunciativas e ideológicas, tais como, professora (nas áreas rural e urbana), sindicalista, esposa, mãe, quebradeira de coco. Os processos de designação dessas diferentes posições colocam em relação discursos que se formulam no interior de diferentes formações discursivas que, pelas circunstâncias históricas ora se entrecruzam, se familiarizam, ora se denegam, se afastam. Observemos as seguintes sequências discursivas $(\mathrm{SD})$ recortadas da narrativa:

SD1: Fui ser professora na zona rural - já era professora aqui. Fui pra zona rural ser professora, ganhei um pedacinho de terra, e tenho até hoje minha terra (p. 26).

\footnotetext{
${ }^{5}$ Apresentação do livro Sou filha de quebradeira de coco babaçu. (OLIVEIRA, 2017, p. 9) 
SD2: Eu comecei participar eu já tinha uns 17 anos, mas eu já era casada, já mãe de filhos e fui criando meus filhos assim. (p. 39)

SD3: Quando eu era professora, era a Associação dos professores, do SINTEP. Eu sou daqui, sou mulher, sou da Associação de mulher. Discutir a política dessas associação é comigo, sem envolver partido. (...) Organização é o Sindicato, é a Associação. Eu faço parte da associação, pois sou secretária da associação. Sou secretária do Sindicato. (p. 56)

SD4: Então foi o Sindicato dos Trabalhadores Rurais. Então no Sindicato dos Trabalhadores Rurais fazia parte da discussão - fui delegada, tive na delegacia. Eu representava uma delegacia do sindicato. Depois fui pra diretoria do sindicato. Fui vice-presidente do sindicato, secretária. (p. 87).

SD5: Eu sou filha de quebradeira de coco. Tive oportunidade mais um pouquinho que minha mãe e minha avó. Porque no nosso tempo a gente tinha vergonha de dizer: o que faz. O que sustentava nossa família e hoje com esse estudo, com essa disposição das universidade, das pessoas que tem um conhecimento, que valoriza o trabalho, a gente se sente já, mais diferente, né? E valorizado também, não tem vergonha de participar, de falar nossa língua, de saber que é bem diferente nosso jeito até de pensar, até de agir com quem tem o conhecimento. Mas a gente age conforme tá acontecendo. (p. 118).

SD6: As quebradeiras de coco tem hoje... criamos uma cooperativa, da qual eu sou a coordenadora geral. Então foi por aí que eu vim chegando no movimento e aí entrei. Já fui coordenadora por três mandatos aí não pude mais ser coordenadora, mas, fiquei sendo, assim mesmo, voluntária, porque não poderia ser uma coordenadora eleita porque o nosso estatuto do MIMQC diz que é só três mandato. (p. 88)

Embora essas posições possam parecer constituir uma homogeneidade e ancoradas em um sujeito uno, que reunindo em uma única modalidade discursiva todas as posições ocupadas e referidas, entendemos com a Análise de Discurso que o sujeito é sempre contingente porque é histórico. Nesse sentido, sujeito e linguagem se constituem na relação com dadas condições históricas, de modo que, embora os lugares sociais e as posições discursivas se cruzem em um mesmo indivíduo, a constituição da forma-sujeito se dá por diferentes historicidades, podendo haver posições que se filiem a um mesmo discurso e posições que deneguem o discurso de outra formação discursiva ocupada pelo mesmo sujeito.

Assim, na primeira sequência discursiva em que a narradora se designa como professora, é possível apreender nessa designação uma bifurcação de sentidos: a professora da zona rural e a professora daqui (área urbana). A professora que estaria indo para a zona rural, para além da função de professora a ser exercida, estaria, também, integrando-se ao cotidiano de trabalhadora rural ("Fui pra zona rural ser professora, ganhei um pedacinho de terra, e tenho até hoje minha terra"), o que extrapola o papel de professora da escola básica. Atentemos para o fato de que nessa sequência discursiva-textual há uma justaposição de formulações (" $F u i$ pra zona rural ser professora" / "ganhei um pedacinho de terra") produzindo o efeito de uma relação indissociável entre ser professora e cultivar a terra, uma relação de implicação, embora desprovida de qualquer operador argumentativo. À condição de professora da área rural 
acresceu-se a de trabalhadora rural materializada na designação "minha terra". Não se trata, portanto, apenas de mudança da cidade para o campo onde continuaria atuando na profissão docente, mas, de mudança de territorialidades, em que o campo, com diferentes sentidos construídos sobre ele, passa a ser para Cledeneuza o lugar de produção da vida material e também simbólica e ideológica, uma vez que "minha terra", no contexto da luta pela terra, implica trabalhar e cultivar a terra, mas também incorporar sentidos da luta de quem trabalha nela.

As designações presentes nas SDs 2 a 6 materializam as diferentes posições ocupadas por Cledeneuza das quais fala por meio da forte relação com a terra, inserindo nessa relação diferentes emergências que compõem o arquivo da luta pela terra que, discursivamente tem sido luta de homens, apenas. As mulheres têm sido representadas nesse espaço por meio da ocupação de papéis supostamente menos decisivos na luta pela posse da terra.

Na formulação “comecei participar eu já tinha uns 17 anos, mas eu já era casada, já mãe de filhos e fui criando meus filhos assim", há, na materialidade discursiva, vários índices linguísticos cujos sentidos desequilibram esse estereótipo da masculinidade como centro da luta pela terra: adolescente, esposa e mãe são dimensões de uma formação discursiva de resistência feminina que, no domínio da luta pela terra, dela participa com as múltiplas dimensões do ser mulher. Na formulação "E fui criando meus filhos assim”, o assim funciona como um recurso encapsulador de uma memória em que a recriação da vida familiar e social se entrelaçam, embora guardem suas especificidades. Por outro lado, essa mesma formulação remete ao trabalho amplo da mulher- mãe, professora, agricultora, militante- que sofre silenciamentos na história do patriarcado. Esse discurso revela a dupla face do jogo entre tentativas de silenciamento e a inquietude das resistências, pois, como discute Silva (2008), raramente se encontra, sobretudo nas narrativas de migração e de luta pela terra na Amazônia, uma narrativa na qual a mulher tome a palavra e afirme posições ocupadas nesse espaço de luta, embora elas estejam sempre presentes no processo de ocupação e recriação das relações sociais.

Outras designações presentes nas SDs 3, 4, 5 e 6 reforçam a multiplicidade de lugares que a enunciadora ocupa em sua trajetória de militância na educação e na organização sindical de trabalhadores e trabalhadoras rurais: secretária da Associação da Mulher; secretária do Sindicato de Professores; delegada (do Sindicato dos Trabalhadores Rurais), vice-presidente do Sindicato dos Trabalhadores Rurais); secretária (do Sindicato dos Trabalhadores Rurais), quebradeira de coco, coordenadora geral da cooperativa do MIQCB. As designações inscritas nessas quatro sequências discursivas, além de reforçarem a identificação do sujeito com diferentes formações discursivas (educacional, sindical, das trabalhadoras do campo, entre 
outras) e seu ajustamento a elas em cada momento histórico, revelam também que tal identificação é sempre imaginária, móvel, pois todo ajustamento do sujeito a uma e outra formação discursiva é sempre inacabado. Como postula Pêcheux (1995 [1975]), a identificação imaginária se dá pelo apagamento do efeito que ela própria produz, de forma que, afetado pela evidência do sentido, o sujeito se coloca como origem da sua relação com a identificação, responsável pelas mudanças de processos identitários.

Embora todas as posições assumidas em cada função se centrem imaginariamente no eu individual representado pela primeira pessoa, configurando-se como uma identidade autônoma de um sujeito dono de suas vontades, origem de suas decisões, tal evidência do sujeito é efeito mesmo da ideologia que dissimula os processos que determinam essas posições em cada momento histórico. Para Pêcheux (1995 [1975], p. 155), "a evidência da identidade oculta que esta resulta de uma 'identificação-interpelação', cuja origem estranha é, contudo, 'estranhamente familiar'”, ou seja, é no jogo das representações ideológicas que o sujeito vai se constituindo pela identificação com a formação discursiva que orienta seu próprio processo de identificação.

Na SD5, observamos uma construção identitária que se dá por transformação: "Porque no nosso tempo a gente tinha vergonha de dizer [...] e hoje com esse estudo, com essa disposição das universidade [...] a gente se sente já, mais diferente, né? E valorizado também, não tem vergonha de participar, de falar nossa língua [...]'. Identificamos aqui a tomada de posição de que fala Pêcheux: ante os saberes e as determinações da formação discursiva em que o sujeito está inscrito, passa de uma posição de submissão e vergonha a uma posição de autovalorização.

Se nas sequências acima o efeito de evidência de identidades está relacionado aos ajustamentos que o sujeito opera ao assumir diferentes posições, na SD 7, logo a seguir, temos processos de desidentificação atuando na constituição do sujeito que narra.

\section{Desidentificações e práticas de resistência}

SD 7: Eu ficava aqui na rua, não tinha lote, o meu companheiro não queria entrar na luta. Mas ele era sindicalizado, não era eu. Porque naquele tempo a mulher era "dependente" do marido. Mas, eu acompanhava as reuniões. Eles não se importavam eu ia. (...) ele não gostava, não se interessava eu ocupei o lugar dele. Eu ia pra reunião, que ele era sócio, então eu queria tá lá. (p.47)

SD8: O sindicato foi assim: quando os homens tava na luta pra ganhar a terra, era pouca gente, só os homens que era sócio. Então levava lá o advogado, levou lá, apareceu advogado - essa coisa toda - levava a reivindicação de 300 família (...) que eram os que tavam lutando pela terra. Quer dizer, mas era mais 330 só, sendo que mais as mulheres dava seiscentos. 
Aí quando começou esse estudo de dizer: quanto eu tô beneficiando? Quantos tão lutando? Então não era só os homens. Aí foi feito - o sindicato já saiu da mão do pelego, já tinha lutado o sindicato pra sair da mão do pelego - então na assembleia foi discutido que as mulheres também ia se associar. Porque aumentava o número de sócio e o dinheiro pra o trabalho. Porque só vivia da mensalidade, então era muito pequena a mensalidade. E se o homem e a mulher pagassem, tinha mais dinheiro pra poder fazer as viagens, pra poder resolver as coisas.

Foi assim que a mulher foi fazer parte do sindicato. Nós se associamos no sindicato. E também dentro disso aí- esse direito de nós se associar - tem o direito de nós reivindicar, que nós queria um grupo só pra nós - pra nós discutir nosso problema. Porque com os homens era assim: A gente tinha um ponto de pauta, não era ponto de pauta, era como informe. Aí eles discutiam, discutiam e quando tava todo mundo cansado, que já vai embora: "- ah, as mulheres têm um informe aqui!"

A gente não aceitou mais ser só informe. Nós queria discutir a nossa situação também. Como os homens discutia os problemas, as mulheres também tinha que discutir. Foi daí que criou o momento. Foi daí que a gente veio pro movimento com esse objetivo que a gente tem hoje. (p.75-76)

Ao problematizar a racionalização do poder como um processo que perpassa vários campos com referências, experiências e racionalidades específicas, Foucault (1995[1982]) assevera que para analisar as formas de poder dessa perspectiva é necessário levar em consideração as formas de resistência como "catalizador químico", localizando a posição que o poder ocupa e os métodos utilizados a partir de antagonismos e estratégias (sanidade/insanidade; louco/não louco; idoso/jovem; mulher/homem) que evidenciem a relação poder X resistência. Ou seja, trata-se de uma perspectiva em que o poder não é tomado como força central e unificadora, uma vez que sua existência demanda um jogo de relações de força com as resistências constitutivas de diferentes tipos de poder.

Em contraposição a esse olhar orientado para a centralidade do poder, Foucault adverte que dentre os três principais tipos de lutas presentes em nossa sociedade - as lutas contra as formas de dominação social, étnica e religiosa; as lutas contra as formas de exploração em relação ao que o indivíduo produz; as lutas contra aquilo que liga o indivíduo a si mesmo e o submete aos outros pela sujeição, subjetivação e submissão - as lutas contra as formas de sujeição, subjetivação e submissão tornam-se a cada dia, o mais importante tipo de luta, na sociedade contemporânea, o que não significa dizer que as formas de dominação e exploração tenham desaparecido, pelo contrário, elas estão mais do que nunca em forte funcionamento. No entanto, a atenção de Foucault para esse terceiro tipo de luta se deve ao fato de que as microlutas, embora não tenham recebido a mesma centralidade que as lutas econômicas e superestruturais, elas são importantes porque afirmam a diferença e enfatizam o que torna os indivíduos verdadeiramente individuais. Por outro lado, colocam em questão os mecanismos políticos que fragmentam a vida comunitária e que forçam o indivíduo a voltar para si mesmo e a se relacionar com sua própria identidade de forma coercitiva. (FOUCAULT, 1995[1982]). 
Considerando esta atenção especial de Foucault para as lutas contra a sujeição, submissão e subjetivação, gostaríamos de situar o discurso que se materializa nas SDs 7 e 8 nesse domínio das microlutas e das resistências. Trata-se de uma narrativa cujo efeito é de contraidentificação ao discurso da exclusão da mulher numa sociedade do patriarcado. Percorrendo o fio do dizer, é possível apreender na narrativa de Cledeneuza a posição de liderança que ela ocupa no Sindicato dos Trabalhadores Rurais, a partir de um jogo de forças com seus companheiros militantes, homens. Antes, essa relação de força se explicita em sua própria família, com o companheiro conjugal com quem, segundo ela, mantinha uma relação de dependência ("Porque naquele tempo a mulher era 'dependente' do marido"), situação que é remetida a um passado ("era 'dependente' do marido"). Se, por um lado, Cledeneuza se diz dependente do marido, no passado, nesse passado mesmo, a condição de dependência enunciada produz deslocamentos possíveis dentro dessa ordem discursiva ("Mas, eu acompanhava as reuniões. Eles não se importavam eu ia. (...) ele não gostava, não se interessava eu ocupei o lugar dele"). Acompanhar o companheiro nas reuniões do sindicato constituiu-se nessa relação silenciosa uma possibilidade de ocupar a posição do marido no sindicato.

Na sequência do arranjo discursivo-textual dessa narrativa, materializa-se, ainda, um jogo de forças entre formações discursivas que, embora estejam participando de uma mesma estratégia de luta face às determinações do poder estatal, que são os homens associados aos sindicatos e as mulheres impedidas de se associarem. Esses sujeitos se enfrentam em lutas internas, em microlutas, em uma forma de poder que se aplica à vida cotidiana e categoriza o indivíduo, impõe-lhe uma verdade, uma identidade, subjetivando-o. Nesse discurso subjaz a denúncia de que as mulheres só puderam ocupar a posição de sócias do sindicato em razão de uma racionalidade das lideranças masculinas do sindicato: “O sindicato foi assim: quando os homens tava na luta pra ganhar a terra, era pouca gente, só os homens que era sócio.(...) Quer dizer, mas era mais 330 só, sendo que mais as mulheres dava seiscentos.(...) então na assembleia foi discutido que as mulheres também ia se associar. Porque aumentava o número de sócio e o dinheiro pra o trabalho."

Observe-se que na formulação "então na assembleia foi discutido que as mulheres também ia se associar", a forma apassivadora "foi discutido" coloca o foco na decisão de um outro, possivelmente os homens do sindicato, que decidem sobre a filiação das mulheres. Impõe-se uma racionalidade técnica, quantitativa e lucrativa que, somente por meio dela é possível justificar a participação das mulheres como filiadas ao sindicato: "Porque aumentava o número de sócio e o dinheiro pra o trabalho." Se a racionalidade numérica resolve um cálculo 
pontual de arrecadação de recursos - o que é importante e necessário para o sindicato levar adiante o trabalho -, vale observar que isso não é suficiente para a superação das práticas divisoras que permanecem no interior da luta de trabalhadores e trabalhadoras, uma vez que o protagonismo das mulheres não era reconhecido. Isso mostra que o enfrentamento do poder estatal precisa ocorrer ao lado do enfretamento dos pequenos poderes, das lutas transversais, no espaço mesmo do cotidiano.

No entanto é na sequência dessa formulação que podemos apreender o "caráter oscilante e paradoxal no registro ordinário do sentido" de que fala Pêcheux (2008 [1983], p. 52), ao trazer à discussão a ideia de que "todo enunciado é intrinsecamente suscetível de tornar-se outro, diferente de si mesmo, se deslocar discursivamente de seu sentido para derivar para um outro [...]" (PÊCHEUX, 2008 [1983], p. 53). É inspiradas nessa abordagem do autor que podemos apreender o deslocamento de sentidos produzidos nessa narrativa, a partir das formulações: "Nós se associamos no sindicato. E também dentro disso aí- esse direito de nós se associartem o direito de nós reivindicar, que nós queria um grupo só pra nós - pra nós discutir nosso problema." De uma posição de participante do sindicato para compor a lógica pautada na quantidade de sócios, uma outra posição é enunciada produzindo um deslocamento marcado nas formulações "direito de associar", "direito de reivindicar", "um grupo só pra nós", "discutir nossos problemas".

Esse discurso revela uma potência que instaura uma nova posição cujo efeito é de “desidentificação" (PÊCHEUX, 1995 [1975]) em relação à posição anterior ocupada pelas mulheres. As formas pronominais nós e o nosso remetem, agora, nessa nova formulação, a uma coletividade, com suas especificidades ideológicas. No espaço da reconfiguração dessa formação discursiva, em "A gente não aceitou mais ser só informe”, a negação marca a mudança de posição, retomada pelas formulações: "Nós queria discutir a nossa situação também; Foi daí que a gente veio pro movimento com esse objetivo que a gente tem hoje." Para Pêcheux (1995 [1975]), uma tal posição, a partir da qual o sujeito se separa daquilo que ele toma consciência não deve ser vista como uma saída do sujeito para fora da ideologia, numa posição "politicamente heróica" e "epistemologicamente teleológica". Da perspectiva assumida pela $\mathrm{AD}$, segundo a qual não há sujeito sem ideologia, uma tal mudança de posição - ou ainda o surgimento de uma nova posição em uma formação discursiva, reconfigurando-a - deve ser entendida como forma subjetiva da prática política que afeta o trabalho desidentificador, desenvolvido por meio de novas identificações, por meio da interpelação às avessas. (PÊCHEUX, 1995). Parece ser esse o funcionamento discursivo que se opera no discurso em análise. Embora a discursividade, aqui, não aconteça numa relação entre superestrutura e 
proletariado como analisa Pêcheux, mas, entre dois espaços discursivos não estabilizados, ambos no domínio da vida cotidiana de trabalhadores e trabalhadoras rurais, trata-se de disputa ideológica (de gênero).

\section{A construção distópica do tempo-espaço: historicidade da experiência-limite}

De acordo com Agamben, "toda concepção da história é sempre acompanhada de uma certa experiência do tempo que lhe está implícita, que a condiciona e que é preciso, portanto, trazer luz" (AGAMBEN, 2008 [1978], p. 111). Rejeitando qualquer concepção de tempo como algo circular, objetivado e natural no mundo clássico, ou como sucessão retilínea e infinita do mundo cristão, ainda presentes em concepções modernas de tempo, o autor, postula que "toda cultura é, primeiramente, uma certa experiência do tempo, e uma nova cultura não é possível sem uma transformação dessa experiência" (Ibid.). A estas concepções de tempo como progresso contínuo, Agamben opõe o tempo pleno, finito e descontínuo do prazer. Trata-se da suspensão do tempo cronológico em favor de uma mudança qualitativa do tempo, em que se suspende a duração mensurável do tempo em favor da experiência do prazer como algo necessário e mais revolucionário da dimensão humana.

Se Agamben aborda o tempo a partir da mudança qualitativa da cronologia e não da perspectiva da duração mensurável do tempo, Foucault (2009[1967]) aborda as localizações heterotópicas, observando que enquanto a história é a obsessão do século XIX, a nossa época é a época dos espaços, embora admita que é impossível esquecer que há um nó profundo entre o tempo e o espaço.

Estamos na época do simultâneo, estamos na época da justaposição, do próximo e do longínquo, do lado a lado, do disperso. Estamos em um momento em que o mundo se experimenta, acredito, menos como uma grande via que se desenvolveria através dos tempos do que como uma rede que religa pontos e que entrecruza sua trama. (FOUCAULT, 2009[1967], p. 411).

Assim, para Foucault (2009[1967]), enquanto na Idade Média prevaleceu uma relação hierárquica dos lugares, representada pelas dicotomias entre sagrados x profanos, protegidos $\mathrm{x}$ expostos, urbanos x rurais, distribuídas em sítios específicos, na sociedade contemporânea, esses sítios se desfizeram e passaram a se definir por relações de proximidades, atravessados por redes de relações que não são próprias de um único sítio, embora não se possa dizer que nossa vida moderna não seja mais regida por muitas dicotomias.

O espaço no qual vivemos, pelo qual somos atraídos para fora de nós mesmos, no qual decorre precisamente a erosão de nossa vida, de nosso tempo, de nossa história, esse 
espaço que nos corrói e nos sulca é também em si mesmo um espaço heterogêneo. Dito de outra forma, não vivemos em uma espécie de vazio, no interior do qual se poderiam situar os indivíduos e as coisas. Não vivemos no interior de um vazio que se encheria de cores com diferentes reflexos, vivemos no interior de um conjunto de relações que definem posicionamentos irredutíveis uns aos outros e absolutamente impossíveis de ser sobrepostos. (FOUCAULT, 2009[1967], p. 414).

Interessa a Foucault, justamente essa rede de relações entre espaços que se encadeiam, se contradizem, se superpõem, e o autor destaca dois tipos principais de sítios, em nossa sociedade: as utopias e as heterotopias. Os espaços utópicos são, para Foucault, lugares irreais, projetados e que mantêm com a sociedade uma relação de aperfeiçoamento ou de inversão dos lugares numa dada cultura. Já as heterotopias estão relacionadas ao princípio de que nenhuma cultura existe sem as suas heterotopias, assumidas de diferentes formas, já que para Foucault (2013), não se vive, não se morre, não se ama no retângulo de uma folha de papel, mas sempre em um "espaço quadriculado, recortado, matizado, com zonas claras e sombrias, diferenças de níveis, graus de escada, vãos, relevos, regiões duras e outras quebradiças, penetráveis, porosas. (FOUCAULT, 2013, p. 19).

É por meio da articulação da heterotopia com o tempo, aqui assumido como tempo qualitativo, como propõe Agamben, que pretendemos apreender discursivamente, efeitos de sentido produzidos na experiência em que o sujeito vai se constituindo afetado por deslocamentos históricos, no tempo e no espaço imaginariamente construídos.

SD 9: No início minha família que não era formada por homens, era por mulher, só depois que casou as filhas, os genros, puxou né? A minha avó veio do Maranhão, foi pra Itupiranga, na época da borracha. Meu tio, irmão da minha avó, era soldado da borracha. A minha bisavó... eles voltaram pro Maranhão, e a minha avó ficou no Itupiranga. De Itupiranga ela desceu pra Marabá, porque... era também povoado Marabá. Achava que Marabá era melhor e mudou pra Marabá. (p. 20)

SD 10: O meu pai tirou uma terra ali [...] saindo da vicinal São Benedito, na Água Branca. Ele tirou um lote, mas, era muito difícil o acesso, ele deixou a terra. Antigamente a gente não valorizava, fazia a roça onde queria. Saía daqui: "Ah, aqui era bom pra fazer uma roça" ia lá fazia a roça. A gente não era diretamente dono de lote. Só alguns cercavam de madeira e ficava usando aquela parte dele, e os outros não, hoje fazia uma roça aqui, duas roças aí: "não, aqui já não tá bom". Ia fazer mais distante. A criação do outro perturbava, ele já ia pra frente. A terra não era de dono, era só onde a gente quisesse ficar. (p 35).

As SDs 9 e 10 trazem marcas da relação heterotópica entre tempo e espaço, de forma que a terra se constitui no lugar heterotópico produtor de territorialidades que afetam a vida material e simbólica dos sujeitos. Nessas sequências que, aparentemente, remetem apenas a uma história cronológica e linear do tempo, há rupturas, deslocamentos que se produzem sob o efeito da relação dos sujeitos com a história da luta mais ampla pela posse da terra em uma região da Amazônia oriental brasileira marcada historicamente por intensos conflitos entre 
trabalhadores e a oligarquia local, o fazendeiro, os latifundiários, os grandes projetos etc., cujos desfechos foram marcados de mortes, chacinas e massacres de trabalhadores e trabalhadoras rurais. Significa que há, na sociedade brasileira - particularmente na região amazônica que ainda vivencia intensos conflitos e a luta pela terra -, múltiplas representações sobre a terra, com funções heterotópicas dicotômicas e antagônicas.

Assim, na SD 9, a narradora produz em seu relato o percurso de chegada da sua família à localidade onde reside até hoje. As formas verbais vir, ir, voltar e descer (pelo rio) não apenas referenciam meros deslocamentos das famílias em direção a uma localidade dessa região, mas também sugerem heterotopias móveis de sujeitos que fizeram parte de uma dinâmica social representada por diferentes ciclos econômicos, sobretudo a partir da década de 50 do século $\mathrm{XX}$, por meio de processos migratórios.

Em sua narrativa, Cledeneuza relata que a família migrou de seu Estado de origem, justamente no momento em que ocorria um dos fluxos migratórios para a Amazônia, sobretudo para o sudeste paraense, de pessoas que vinham da região Nordeste do país, particularmente dos estados do Maranhão e Piauí. (HÉBETTE, 2004). Para esses sujeitos em processos de deslocamentos migratórios impulsionados pela distopia da sobrevivência, a terra tem o sentido heterotópico de espaço de produção de existência, mas, também, de resistência. Vejamos que os deslocamentos forçados pela busca de sobrevivência não ocorrem apenas da região Nordeste (Maranhão) para a região Norte (Pará), mas, também, de uma cidade para outra, na própria região Norte: “A minha avó veio do Maranhão, foi pra Itupiranga; De Itupiranga ela desceu pra Marabá." O ciclo econômico impulsionador dessa distopia foi a extração da borracha, na região Amazônica (“... na época da borracha. Meu tio, irmão da minha avó, era soldado da borracha"), de modo que os sujeitos se deslocam seguindo a heterotopia dos sonhos ("De Itupiranga ela desceu pra Marabá, porque... era também povoado Marabá. Achava que Marabá era melhor e mudou pra Marabá”).

Assim a terra se apresenta para esses sujeitos como a heterotopia que move seus sonhos ao migrarem de uma região para outra em busca de condições dignas de vida, pois como lembra Foucault, "o espaço dos nossos sonhos e o espaço das nossas paixões encerram em si próprios qualidades à primeira vista intrínsecas: há um espaço luminoso, etéreo e transparente, ou um espaço tenebroso, imperfeito e que inibe os movimentos" (FOUCAULT, 2009[1967], p.412). No caso da narrativa de Cledeneuza, observamos que, ao migrarem, os sujeitos sonham com um espaço luminoso da sobrevivência, embora, quando chegam à "terra prometida", muitos se deparam com espaços tenebrosos, imperfeitos. 
Nesse sentido, na SD 10 é possível perceber, nas diferentes formulações, como a terra significa para os sujeitos migrantes tanto o lugar compatível com a possiblidade de melhores condições de vida, como o espaço que sempre escapa daquele que por ela luta como a única possiblidade de se manter vivo. As formulações "tirou uma terra", "tirou um lote", "era muito difícil o acesso" e "deixou a terra" colocam em funcionamento o discurso no seu avesso. O que poderia significar uma conquista dos trabalhadores em relação à posse da terra, com a aquisição de um lote, transforma-se em interdição desse sonho por sentidos que remetem à negação de direitos: "difícil acesso" e "deixou a terra" são duas situações que se naturalizam nesse movimento distópico representado por pobreza, migração, luta pela terra e negação de direito, de forma que o sujeito está sempre em retorno ao ponto zero, a novas lutas, a novas conquistas da terra porque são os grandes fazendeiros, a cumplicidade do Estado e os grandes projetos que sempre adiam ou interditam esse sonho, até mesmo com a morte dos trabalhadores e trabalhadoras.

Nesse discurso, o passado coloca o sujeito numa relação com um tempo longínquo, em que as possibilidades de concretização do sonho e do desejo são remetidas a uma experiência provisória. Vejamos que a experiência coletiva de trabalho agrícola numa terra que ainda não era de um único dono, ou sequer havia dono algum, foi remetida ao passado, a uma temporalidade longínqua que não se repete: "A gente não era diretamente dono de lote"; "A terra não era de dono, era só onde a gente quisesse ficar".

Esse discurso do passado se atualiza em outras condições históricas que emergem no discurso da narradora. Trata-se agora de um outro sujeito - o fazendeiro - que, legitimado como o dono da terra, trava novos embates com novas subjetividades que também sobrevivem do trabalho na terra: as mulheres quebradeiras de coco.

SD 11: Além da ameaça, que o babaçu ficou longe. Nós não tem recurso pra trazer ele pra perto de nós. Que precisa transporte, precisa juntar. Antigamente não, a gente ia lá no mato, fazia o monte lá embaixo da palmeira. Não gastava muita coisa. Agora, hoje não. Tem que carregar na costa pra botar fora do arame, aonde, num ponto que o carro pegue. Não pode quebrar em qualquer lugar, porque os donos da terra não aceita. (p. 97).

A narradora atualiza o discurso da luta pela terra com a mesma negação de direitos materializada na SD 10, no momento do fluxo migratório para a Amazônia. Se, quando os migrantes chegaram à região, na década de 1950, a terra era de quem nela trabalhava, portanto não possuía um dono exclusivo, nos dias atuais, não apenas há um dono da terra, mas, há, também, ameaça à vida daqueles e daquelas que resistem em se manterem na terra. 
Na SD 11, temos no discurso das mulheres quebradeiras de coco babaçu, uma outra dinâmica de trabalho produzida por grupos de mulheres dos Estados do Pará, Maranhão, Piauí e Tocantins, como já mencionamos. As formulações "ameaça", "longe" e "não tem recurso" caracterizam heterotopias que produzem sentidos contrários às heterotopias dos sonhos que impulsionaram os sujeitos migrantes a se deslocarem de seus Estados de origem para uma Amazônia em busca de terra e trabalho. A heterotopia dos sonhos no discurso das mulheres quebradeiras é contraposta também pela negação de direitos, opressão, ameaça à vida, assim como ocorreu com os trabalhadores que migraram para a região em busca de terra. No entanto, se no período do fluxo migratório de pessoas da região nordeste do país para a Amazônia, a luta se instaurava em função da disputa pela terra, agora, a luta que as mulheres travam é com o dono da terra cuja posse já foi há vários anos oficializada pelas instituições estatais. Nesse sentido, nas formulações “Antigamente não, a gente ia lá no mato, fazia o monte lá embaixo da palmeira. Não gastava muita coisa", o sujeito recorta o tempo e estabelece entre ele e a terra uma relação de possiblidades de realização da atividade de extração do coco babaçu. Assim, Antigamente não é um retorno ao passado em que o trabalho de extração do coco babaçu era possível. Ao passo que na sequência "Agora, hoje não. Tem que carregar na costa pra botar fora do arame, aonde, num ponto que o carro pegue. Não pode quebrar em qualquer lugar, porque os donos da terra não aceita", em "Agora, hoje não", circunscrevem-se outras condições de produção de discurso. Se a negação em Antigamente abre, na continuidade da frase, a possiblidade de execução da atividade das quebradeiras de coco, a negação em "Agora, hoje não", encadeia, na sintaxe da frase a impossibilidade de concretização da mesma atividade antes exercida pelas mulheres. Na linguagem, instaura-se uma impossibilidade que restringe e interdita corpos através das cercas de arames farpados, metáfora da exclusão das mulheres e aprisionamento dos babaçuais sob o domínio do fazendeiro.

\footnotetext{
As heterotopias inquietam, sem dúvida porque solapam secretamente a linguagem, porque impedem de nomear isto e aquilo, porque fracionam os nomes comuns ou os emaranham, porque arruínam de antemão a "sintaxe", e não somente aquela que constrói as frases - aquela, menos manifesta, que autoriza "manter juntos " (ao lado e em frente umas das outras) as palavras e as coisas. (FOUCAULT, 2000[1966], p. 9).
}

No entanto, ainda que sob a interdição, os corpos se movem, justamente porque a ideologia dominante não é um bloco compacto sem possibilidades de falhas. Com isso não significa inclinar-se, como alerta Pêcheux (2008[1983]), para tendências ideológicas que consideram os sentidos do cotidiano como um fenômeno de natureza psico-biológica, como já refletimos acima. Se quisermos apreender, no jogo das forças do poder as estratégias de 
resistência, devemos nos colocar à escuta dos discursos ordinários, sobretudo no que eles trazem de marcas de sobrevivência e resistência, como podemos apreender na SD 11:

SD 12: Primeiro tem que manter a nossa tradição. Preservar a natureza e manter as nossas tradição! Esse é o forte de nós: é não deixar acabar nossa história. Quem fomos? Quem somos? Esse é o nosso objetivo. E preservar essa natureza, porque nós, as únicas que briga - que tá brigando. Que tá pelejando pra preservação dos babaçuais, somos nós. (p. 109).

A modalização "tem que" é uma importante formulação por meio da qual se materializa um discurso que assume uma posição de resistência. Uma resistência que projeta, instaura uma potência e uma persistência face ao domínio do poder. A modalização funciona como a base que sustenta outras formulações verbais no infinitivo: manter, preservar e não deixar. Mas, quem tem que manter, preservar a natureza e não deixar morrer a história? Na equivocidade da linguagem e do sujeito, tanto a geração atual de mulheres quebradeiras de coco quanto gerações futuras devem manter nossa tradição, nossa história, articulada a um futuro marcado nas formas verbais que sugerem o vir-a-ser, que não se vincula a um sujeito específico. O presente, por sua vez, se revela nas lutas cotidiana e contínuas dessas mulheres que resistem de muitas maneiras, sob a denúncia de uma luta solitária: "as únicas que briga-que tá brigando. Que tá pelejando pra preservação dos babaçuais."

\section{Considerações finais: a luta individual e coletiva}

O olhar teórico-analítico com o qual percorremos a narrativa da trajetória de vida da "filha de quebradeira de coco babaçu" nos permitiu explorar uma heterogeneidade constitutiva da subjetividade e do próprio discurso. Nas sequências discursivas recortadas, deparamo-nos com lugares sociais e posições assumidas, como num quarto de espelhos, em que as múltiplas faces não se opõem, sequer se distanciam, mas se complementam na construção subjetiva: mulher, professora, quebradeira de coco babaçu, filha de quebradeira de coco, filha e neta de sujeitos em trânsito, esposa, militante, líder sindical. Observamos uma conjunção que forma a personificação de uma subjetividade que é, ao mesmo tempo, múltipla e única.

Essa personificação nos é apresentada já na capa do livro, onde é possível associar, por correferenciação: a) o nome próprio Cledeneuza Maria Bizerra Oliveira, que, por sua posição de único nome próprio presente na capa, identificamos como autora única do livro - ainda que nas orelhas (e no prefácio), Rita de Cássia Pereira da Costa ${ }^{6}$ nos conte: "Este livro consiste em

\footnotetext{
${ }^{6} \mathrm{O}$ texto das orelhas é um trecho do prefácio (COSTA, 2017, p.11)
} 
uma espécie de lide coautoral para sistematizar as entrevistas, relatos e falas [...]”, o que já expusemos em seção anterior; b) a corporalidade da autora na foto de uma mulher posta na posição de falante ao microfone - corporalidade de uma foto escolhida entre tantas outras possíveis em que Cledeneuza poderia ter sido apresentada em outras posições possíveis; c) e o enunciado marcado em primeira pessoa que predica Cledeneuza: "Sou filha de quebradeira de côco ${ }^{7 "}$. Assim, essa que reconhecemos como Cledeneuza nos é apresentada como suporte do discurso. Mas não podemos nos esquecer de que é também efeito dele.

Também nas orelhas do livro, deparamo-nos com um espelhamento individualidadecoletividade nessa construção subjetiva, como neste trecho:

Em seus relatos e num passeio pela memória é interessante notar como o faz de maneira a universalizar sua experiência ao dar ensejo à coletividade e em particular lançando apontamentos para vários companheiros de luta. São coletividades que emergem a compor aspectos da história social e em destaque as atuações políticas e caminhos entretecidos no contexto da região sudeste do Pará e fora. A que se tem entrada por via da vida pessoal, atuação profissional e pelo protagonismo político em especial na atuação sindical e no movimento das mulheres quebradeiras de coco babaçu. (COSTA, 2017, p.118)

Cledeneuza são muitas em uma. Seu discurso apresenta uma vida pessoal, mas que só se constitui pelo coletivo. Assim, a particularidade do eu traz em si a representatividade do nós.

Com as análises de sequências discursivas apresentadas neste artigo, pudemos observar esse jogo entre a unidade e a heterogeneidade. Deparamo-nos com um sujeito que transita não só entre espaços, mas entre territorialidades, o que indica sua entrada em outros campos simbólicos, resultando em outros discursos. Também encontramos um movimento ao passado a fim de indicar não só suas origens, mas como essas origens situam a autora como filha e neta de mulheres fortes que trazem uma história de deslocamentos e transformações por uma vida melhor. Metamorfoses que não rompem com o antes, mas que acumulam os muitos "eus" e suas vivências. E que fazem proliferar novos sentidos sobre si e sobre a coletividade em que se inclui. Na especificidade da narrativa de vida de Cledeneuza, deparamo-nos com o jogo entre dispersão e contenção, e encontramos a disputa pelos sentidos, a luta política que é tanto pública como privada. E observamos que a multiplicidade e a unificação não são um paradoxo no reconhecimento de si como parte da luta coletiva das mulheres quebradeiras de coco babaçu.

\section{REFERÊNCIAS}

\footnotetext{
${ }^{7}$ Transcrevemos a palavra como consta na capa. Nas outras referências não há o acento.

${ }^{8}$ Extraído da orelha do livro. 
AGAMBEN, G. Infância e história: destruição da experiência e origem da história. Trad. Henrique Burigo. Belo Horizonte: Editora da UFMG, 2008[1978].

ALMEIDA, A. W. B. de. Apresentação da coleção Narrativas das Quebradeiras de Coco Babaçu. In: OLIVEIRA, Cledeneuza Maria Bizerra. Sou filha de quebradeira de coco babaçu. Rio de Janeiro: Casa 8, 2017. p.9-10.

COSTA, R. C. P. Atuação político-social e identidades: trajetória de uma liderança e quebradeira de coco babaçu. In: OLIVEIRA, C. M. B. Sou filha de quebradeira de coco babaçu. Rio de Janeiro: Casa 8, 2017. p. 11-18.

DE CERTEAU, M. Invenções do cotidiano: 1. Artes de fazer. Trad. Ephraim Pereira Alves. 6 ed. Petrópolis, RJ: Vozes, 1994[1980].

FOUCAULT, M. O corpo utópico: as heterotopias. Trad. Salma Tannus Muchail. São Paulo: n-1 Edições, 2013[1966].

FOUCAULT, M. Outros espaços. In: Estética: Literatura e Pintura, Música e Cinema (Ditos e escritos III). Org. Manoel Barros de Motta. Trad. Inês Autran Dourado Barbosa. 2 ed. Rio de Janeiro: Forense Universitária, 2009[1967], p. 411-422.

FOUCAULT, M. A vida dos homens infames. In: Estratégia poder-saber (Ditos e Escritos IV). Org. Manoel Barros de Motta. Trad. Vera Lúcia Avelar Ribeiro. 5 ed. Rio de Janeiro: Forense Universitária, 2006[1977].

FOUCAULT, M. As palavras e as coisas: uma arqueologia das ciências humanas. Trad. Salma Tannus Muchail.8 ed. São Paulo: Martins Fontes, 2000[1966].

FOUCAULT, M. O sujeito e o poder, in H. Dreyfus e P. Rabinow. Michel Foucault, uma trajetória filosófica: para além do estruturalismo e da hermenêutica, Rio de Janeiro: Forense Universitária, 1995[1982], p. 231-249.

FOUCAULT, M. História da sexualidade 2: o uso dos prazeres. Trad. Maria Thereza da Costa Albuquerque.Rio de Janeiro, Ed. Graal, 1984.

HÉBETTE, J. Cruzando fronteira: 30 anos de estudo do campesinato na Amazônia. Belém: Edufpa, 2004. (Vol. I).

LARROSA, J. Tecnologias do eu e educação. In: O sujeito da educação. Petrópolis: Vozes, 1994, p.35-86.

OLIVEIRA, C. M. B. Sou filha de quebradeira de coco babaçu. Rio de Janeiro: Casa 8, 2017.

PÊCHEUX, M. O discurso: estrutura ou acontecimento. Trad. Eni P. Orlandi. 5 ed. Campinas: Pontes Editores, 2008[1983].

Análise automática do discurso. Trad. Eni P.Orlandi. In: GADET, Françoise; HAK, Tony (orgs.) Por uma análise automática do discurso: uma introdução à obra de Michel Pêcheux. 2 ed. Campinas: Unicamp, 1993[1969]. p.61-161.

. Semântica e Discurso: uma crítica à afirmação do óbvio. Trad. Eni P. Orlandi [et al.] 5 ed. Campinas: UNICAMP. 1995[1975].

SILVA, E M. S.; NAPOLITANO, J. E.; BASTOS, S. (orgs.) Pequenos projetos ecossociais de quebradeiras de coco babaçu: reflexões e aprendizados. Brasília: Instituto Sociedade, População e Natureza - ISPN, 2016. 
SILVA, M. I. C. Mulheres migrantes na Transamazônica: construção da ocupação e do fazer política. Tese. Belém: Universidade Federal do Pará/Instituto de Filosofia e Ciências Humanas/Programa de Pós-Graduação em Ciências Sociais, 2008.

Recebido em 10/07/2020. Aceito em 13/09/2020. 